\title{
EKSPERIMENTASI PENERAPAN MODEL PEMBELAJARAN THE POWER OF TWO DITINJAU DARI KEMAMPUAN BERPIKIR KRITIS DALAM PEMBELAJARAN MATEMATIKA
}

\author{
Lalu Wirajaya \\ SMP Negeri 1 Sakra Barat \\ laluwirajaya633@gmail.com
}

\begin{abstract}
Classroom Action Research applied to Grade VIII students of SMPN 1 Sakra Barat, conducted on the basis of the low level of achievement of the Year-End Achievement Test in Mathematics at the 2017.2018 Academic Year, compared to the average achievement of 2017 Semester Final Assessment / 2018. This study was designed with the Kemmis Action model research procedure, with 2 cycles of action in two meetings. In the description of the results of the research cycle I, and II, there was an increase in the process and results of learning Mathematics with the implementation of the learning model the power of two. In the first cycle, the average score of students' knowledge was 53.67, in the second cycle there was an increase of 73.67 , the results of observations of learning activities of students and teachers in cycle I 3, 50 and 2.71 and increased again in cycle II to 4, 36 and 3.14 with the Good category.
\end{abstract}

Keywords: The Power of Two, Mathematics

\begin{abstract}
Abstrak : Penelitian Tindakan kelas yang diterapkan pada siswa kelas VIII SMP Negeri 1 Sakra Barat, dilakukan atas dasar permasalahan rendahnya rata-rata pencapaian Penilaian Akhir Tahun (PAT) mata pelajaran Matematika pada Tahun Pelajaran 2017/2018, dibandingkan dengan rata-rata pencapaian Penilaian Akhir Semester Tahun 2017/2018. Penelitian ini didesain dengan prosedur penelitian Tindakan model Kemmis, dengan 2 siklus tindakan dalam dua kali pertemuan. Secara deskripsi hasil tindakan penelitian siklus I, dan II, terjadi peningkatan proses dan hasil belajar Matematika dengan penerapan model pembelajaran the power of two. Pada siklus I nilai rata pengetahuan siswa diperoleh sebesar 53,67, pada siklus II mengalami peningkatan yaitu 73,67 , hasil observasi aktivitas belajar siswa dan guru pada siklus I 3, 50 dan 2,71 dan mengalami peningkatan lagi pada siklus II menjadi 4,36 dan 3,14 dengan kategori Baik.
\end{abstract}

Kata Kunci : The power of Two, Matematika 


\section{PENDAHULUAN}

Pelaksanaan pembelajaran Kurikulum 2013 menuntut guru dan siswa melaksanakan pembelajaran menggunakan pendekatan scientivic (saintifik), dimana guru menuntun siswa untuk melakukan kegiatan mengamati, menanya, mengobservasi, mengelompokkan dan mengomunikasikan suatu masalah. Pendekatan pembelajaran saintifik membutuhkan sikap mental yang berbeda dibanding dengan pembelajaran secara umum. Sikap mental yang paling berpengaruh dalam keberhasilan pembelajaran saintifik adalah kebiasaan berpikir yang sempurna, karena peserta didik akan mampu menanya, mengobservasi, mengelompokkan dan mengomunikasikan suatu masalah setelah melakukan proses pengamatan yang baik, dan di dalam proses mengamati terdapat proses pembentukan pengertian melalui proses analisis dan proses mengabstraksikan. Proses pembentukan pengertian ini merupakan langkah-langkah dari kegiatan berpikir.

Salah satu karakteristik matematika, yakni matematika memiliki objek kajian yang bersifat abstrak artinya objek matematika adalah objek mental atau pikiran. dan dalam pembelajaran sekolah peserta didik mempelajari fakta, konsep, operasi (skill), dan prinsip. Dari keempat unsur kandungan materi pembelajaran matematika tersebut, sangat terasa permasalahan siswa yang malas untuk berpikir ketika pembelajaran materi yang berhubungan dengan konsep.

Paparan kondisi diatas adalah kondisi yang dihadapi peneliti yang bertugas sebagai guru mata pelajaran matematika di SMP Negeri 1 Sakra Barat setiap hari, dan merupakan tantangan bagi peneliti untuk menemukan langkah pengentasan yang mampu memperbaiki keadaan yang dihadapi. Dari hasil Penilaian Akhir Tahun (PAT) Tahun pelajaran 2018/2017, pelajaran matematika kelas VIII SMP Negeri 1 Sakra Barat menduduki peringkat 12 (Dua belas) dari rata-rata nilai Se kabupaten Lombok Timur dengan rata- rata nilai 4.50, Sedangkan pada Penilaian Akhir Semester (PAS) 2017/2018) Mata pelajaran Matematika SMP Negeri 1 Sakra Barat menduduki peringkat 9 Sembilan Kab.Lombok Timur dengan nilai rata-rata 5.75. Terjadi penurunan 3 (tiga) peeringkat. Kepala SMP Negeri 1 Sakra Barat Dahman ,M.Pd, Menyampaikan kepada kami sebagai guru matematika bahwa" peringkat yang diperoleh mata pelajaran Matematika harus sama-sama kita pikirkan bagaimana upaya 
kita untuk mengembangkan kognitif peserta didik kita" ( disampaikan dalam rapat dinas guru pegawai SMP negeri 1 Sakra Barat).

Berdasarkan hasil analisis yang guru peneliti lakukan terhadap proses pembelajaran matematika pada semester genap 2017/2018 dari catatan-catatan anekdot dan jurnal pembelajaran di simpulkan bahwa kondisi pembelajaran kondisi matematika kelas VIII mengalami kemunduran yang diakibatkan oleh faktor peserta didik dan guru/ peneliti sendiri. Dan peneliti sebagai salah satu guru mata pelajaran matematika di SMP Negeri 1 Sakra Barat pada semester ganjil Tahun pelajaran 2018/2019, berusaha untuk mengentaskan permasalahan dalam pembelajaran Matematika di alami siswa dan berusaha untuk meningkatkan perbendaharaan keterampilan mengelola pembelajaran yang lebih ideal, dan upaya yang ditempuh adalah dengan meningkatkan kemampuan peserta didik untuk memanfaatkan potensi otaknya dalam berpikir untuk mengolah informasi atau materi yang diberikan dalam proses pembelajaran matematika melalui eksperimentasi model pembelajaran the power of two (kekuatan dua kepala).

\section{KAJIAN PUSTAKA}

\section{Model Pembelajaran}

Model pembelajaran adalah seluruh rangkaian penyajian materi ajar yang meliputi segala aspek sebelum sedang dan sesudah pembelajaran yang dilakukan guru serta segala fasilitas yang terkait yang digunakan secara langsung atau tidak langsung dalam proses belajar mengajar. Model mengajar dapat diartikan sebagai suatu rencana atau pola yang digunakan dalam menyusun kurikulum, mengatur materi peserta didik, dan memberi petunjuk kepada pengajar di kelas dalam setting pengajaran atau setting lainnya. ${ }^{1}$

Model pembelajaran adalah kerangka konseptual dan operasional pembelajaran yang memiliki nama, ciri, urutan logis, pengaturan, dan budaya. Hal ini sesuai dengan Permendikbud No.103 Tahun 2014 tentang Pembelajaran pada Pendidikan Dasar dan Pendidikan Menengah, Pasal 2. "Secara umumnya, model pembelajaran adalah cara atau teknik penyajian sistematis yang digunakan oleh guru

${ }^{1}$ Istarani. 2012. 58 Model Pembelajaran Inovatif. Medan : Media Persada 
dalam mengorganisasikan pengalaman proses pembelajaran agar tercapai tujuan dari sebuah pembelajaran".

Dari beberapa pendapat yang dituliskan di atas, dapat dibuat suatu pendapat yang menyimpulkan bahwa model pembelajaran adalah rencana yang dibuat dalam kerangka konseptual dan operasional, untuk menyampaikan sebuah tujuan pembelajaran kepada siswa di kelas dengan acuan kurikulum yang telah ditetapkan.

\section{Konsep Pembelajaran The Power Of Two}

Model pembelajaran aktif dengan metode The Power of Two adalah pembelajaran kekuatan dua kepala yang digunakan untuk meningkatkan pembelajaran yang kooperatif dan untuk menegaskan pentingnya serta manfaat sinergi, karena dua kepala jauh lebih baik dari pada satu kepala. ${ }^{2}$

Menurut Hisyam Zaini, The power of two merupakan aktifitas pembelajaran yang digunakan untuk mendorong pembelajaran kooperatif dan memperkuat arti penting serta manfaat sinergi dua orang. ${ }^{3}$ Strategi ini mempunyai prinsip bahwa berfikir berdua jauh lebih baik dari pada berfikir sendiri.

Kesimpulannya The power of two merupakan strategi memadukan kekuatan dua buah kepala yang berbeda kekuatannya, menjadi kekuatan yang sama untuk mencapai suatu tujuan yang sama pula. Dan secara logika umum yang berlaku kekuatan yang digabungkan akan menghasilkan kekuatan baru yang akan mendatangkan kemenangan.

\section{Karakteristik Pembelajaran Matematika}

Matematika yang dipelajari di sekolah adalah matematika yang materinya dipilih sedemikian rupa agar mudah dialihfungsikan kegunaannya dalam kehidupan siswa yang mempelajarinya. Berhitung adalah cabang matematika yang membahas tentang bilangan dan operasi hitungnya (penjumlahan, pengurangan, perkalian, pembagian, perpangkatan, penarikan akar, penarikan logaritma). dan Secara umum karakteristik matematika adalah: (1) memiliki objek kajian yang abstrak, (2) mengacu

2 Ayuningtyas dkk. 2013. Pengaruh Model Pembelajaran Aktif Dengan Metode The Power Of Two Dan Make A Match Terhadap Hasil Belajar Siswa Kelas X SMA Negeri 1 Sale. Lontar Physics Forum

${ }^{3}$ Hisyam, Zaini. 2002. Strategi Pembelajaran Aktif di PT Yogyakarta: CTDS. 
pada kesepakatan, (3) berpola pikir deduktif, (4) konsisten dalam sistemnya, (5) memiliki simbol yang kosong dari arti, (6) memperhatikan semesta pembicaraan. ${ }^{4}$

\section{Konsep Kemampuan Berpikir Kritis}

\section{Pengertian Kemampuan}

Dalam proses pembelajaran diperlukan adanya kemampuan. Kemampuan awal siswa adalah prasyarat yang diperlukan siswa untuk mengikuti proses belajar mengajar yang akan diikuti selanjutnya. Kemampuan awal siswa dapat dijadikan titik tolak untuk membekali siswa agar dapat mengembangkan kemampuan baru. Menurut Wina Hariasty, kemampuan berasal dari kata mampu yang berarti kuasa (bisa, sanggup) melakukan sesuatu, sedangkan kemampuan berarti kesanggupan, kecakapan, kekuatan. ${ }^{5}$

Dari pengertian tersebut dapat disimpulkan bahwa kemampuan adalah kesanggupan atau kecakapan seorang individu dalam menguasai suatu keahlian dan digunakan untuk mengerjakan beragam tugas dalam suatu pekerjaan. Kesanggupan dalam hal ini merupakan kesanggupan siswa dalam melaksanakan dan mengerjakan apa yang di perintahkan oleh guru dan teman serta mendapatkan hasil yang lebih baik.

\section{Pengertian Berpikir Kritis}

Menurut Ennis, berpikir kritis adalah berpikir secara beralasan dan reflektif dengan menekankan pada pembuatan keputusan tentang apa yang harus dipercayai atau dilakukan. ${ }^{6}$ Oleh karena itu, indikator kemampuan berpikir kritis dapat diturunkan dari aktivitas kritis siswa sebagai berikut : Mencari pernyataan yang jelas dari setiap pertanyaan, mencari alasan, Berusaha mengetahui informasi dengan baik, memakai sumber yang memiliki kredibilitas dan menyebutkannya, memperhatikan situasi dan kondisi secara keseluruhan, berusaha tetap relevan dengan ide utama, mengingat

${ }^{4}$ Sri Wardani, 2010, Implikasi Karakteristik Matematika dalam pencapaian Tujuan Mata pelajaran Matematika di SMP/MTs, Departemen Pendidkan Nasional, Ditjen P4TK Jakarta.

${ }^{5}$ Wina Hariyasti,2014 , Strayegy The power Of Two, http://winasinaga.blogspot.com akses 24 Juli 2018

${ }^{6}$ Hassoubah, 2004, Kemampuan berpikir Kritis dan Kreatif, Rosda Karya bandung; 
kepentingan yang asli dan mendasar, mencari alternatif, Bersikap dan berpikir terbuka, mengambil posisi ketika ada bukti yang cukup untuk melakukan sesuatu, mencari penjelasan sebanyak mungkin apabila memungkinkan, dan bersikap secara sistematis dan teratur dengan bagian-bagian dari keseluruhan masalah.

Selanjutnya menurut Langrehr, untuk melatih berpikir kritis siswa harus didorong untuk menjawab pertanyaan-pertanyaan yang berkaitan dengan hal-hal sebagai berikut : (1) Menentukan konsekuensi dari suatu keputusan atau suatu kejadian; (2) Mengidentifikasi asumsi yang digunakan dalam suatu pernyataan; (3) Merumuskan pokok- popok permasalahan; (4) Menemukan adanya bias berdasarkan pada sudut pandang yang berbeda; (5) Mengungkapkan penyebab suatu kejadian; (6) Memilih fakor-faktor yang mendukung terhadap suatu keputusan. ${ }^{7}$

Berdasarkan pada uraian-uraian yang telah dikemukakan dirumuskan pengertian kemampuan berpikir kritis yang digunakan dalam penelitian ini adalah kemampuan berpikir kritis mencakup: kemampuan mengidentifikasi asumsi tentang relasi dan fungsi yang diberikan, kemampuan merumuskan pokok-pokok permasalahan untuk menatapkan kelompok relasi dan fungsi, kemampuan menentukan akibat dari suatu ketentuan yang dipilih, kemampuan mendeteksi adanya perbedaan berdasarkan pada sudut pandang orang lain, kemampuan mengungkap data/definisi/teorema dalam menyelesaikan masalah yang berhubungan dengan materi relasi dan fungsi.

\section{METODE PENELITIAN}

Jenis penelitian ini adalah Penelitian Tindakan Kelas ( classroom action research). Ebbutt dalam Moleong mengemukakan bahwa PTK adalah kajian sistematis dari upaya perbaikan pelaksanaan praktek pendidikan oleh sekelompok guru dengan melakukan tindakan-tindakan dalam pembelajaran, berdasarkan refleksi mereka mengenai hasil dari tindakan-tindakan tersebut. Penelitian Tindakan Kelas

${ }^{7}$ Ibid 
PTK ) adalah penelitian tindakan yang dilakukan di kelas dengan tujuan memperbaiki/meningkatkan mutu praktik pembelajaran.

Lokasi yang dijadikan sasaran dalam penelitian ini adalah SMP Negeri 1 Sakra Barat, Sekolah tempat peneliti bertugas sebagai guru mata pelajaran matemaika, berdasarkan permasalahan siswa masih banyak yang mengalami kesulitan dalam pembelajaran matematika, dan anak mudah lupa terhadap materi yang diajarkan. Hal ini diakibatkan karena faktor kondisi dan anggapan siswa terhadap mata pelajaran matematika yang kurang positif, berdasarkan angket minat belajar matematika siswa kelas VIII yang telah di sebarkan peneliti untuk mencari akar permasalahan rendahnya pencapaian nilai rata-rata PAT semester genap tahun pelajaran 2017/2018.

Menurut Arikunto, model penelitian tindakan kelas secara garis besar terdiri dari 4 tahap, yaitu menyusun rencana tindakan (planning), pelaksanaan tindakan (acting), pengamatan (observasing), dan refleksi ( reflecting).

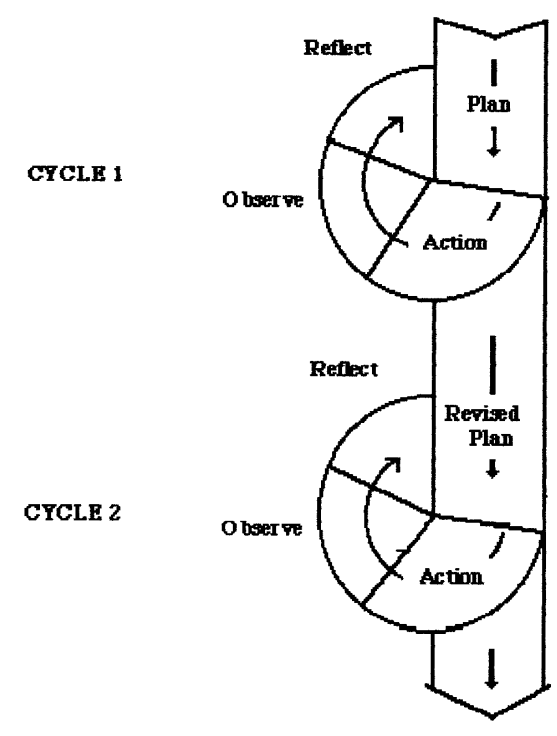

Gambar Penelitian Tindakan Kelas model Kemmis dan Taggart ${ }^{8}$

8 Unila.ac.id.2012, Pendekatan Kualitatif dalam penelitian, http://blog.unila.ac.id/ diakses 25 Agustus 2018 


\section{Perencanaan}

Pada tahap ini yang harus dilakukan adalah menyusun rancangan dari siklus per siklus. Setiap siklus di rencanakan secara matang, dari segi kegiatan, waktu, tenaga, material, dan dana. Hal-hal yang direncanakan diantaranya terkait dengan pembuatan RPP, metode pembelajaran, media dan materi pembelajaran, strategi pembelajaran, mempersiapkan instrumen untuk merekam dan menganalisis data mengenai proses dan hasil tindakan.

2. Tindakan

Pelaksanaan yang dimaksudkan adalah melaksanakan pembelajaran materi bangun datar sesuai dengan rancangan pembelajaran. Rencana tindakan dalam proses pembelajaran adalah sebagai berikut:

a. Melaksanakan pembelajaran sesuai dengan rencana pembelajaran.

b. Mengadakan tes awal

c. Pada akhir pembelajaran dilakukan evaluasi (soal sesuai dengan kemampuan dasar yang terdapat di rencana pembelajaran).

d. Melakukan analisis data.

3. Observasi

Kegiatan observasi adalah mengamati aktifitas selama pembelajaran berlangsung maupun aktifitas peneliti dengan menggunakan lembar observasi yang telah disediakan sebelumnya. Pada tahap ini juga dilakukan pengamatan terhadap kemampuan siswa menguasai kosakata yang diperoleh dari nilai tes lisan dan tes individu. Dalam pelaksanaan observasi dibantu oleh seorang guru mata pelajaran bahasa Inggris dan seorang teman sejawat.

4. Refleksi

Pada kegiatan refleksi, peneliti melakukan diskusi dengan pengamat untuk menjaring hal-hal yang terjadi selama sebelum dan selama tindakan berlangsung berdasarkan hasil pengamatan agar dapat diambil kesimpulan. Kegiatan refleksi dilaksanakan dengan cara menganalisis, memahami, menjelaskan dan menyimpulkan data-data tersebut.

Dalam penelitian ini, keempat tahap di atas dipandang perlu sebagai suatu tindakan. Penelitian ini akan dilakukan beberapa siklus, masing-masing siklus terdiri dari tahap perencanaan, pelaksanaan, observasi, dan refleksi. Setiap 
siklus diakhiri dengan tahap refleksi yaitu sebagai pertimbangan di dalam merumuskan dan merencanakan tindakan yang lebih efektif pada siklus berikutnya. Apabila pada siklus I belum dapat mencapai tujuan yang diinginkan maka dilanjutkan pada siklus II dan seterusnya. sampai tujuan yang diinginkan tercapai. Siklus tindakan akan dihentikan jika siswa telah mencapai pemahaman sesuai indikator yang ditentukan. Indikator dalam penelitian tindakan kelas ini dilihat dari peningkatan kemampuan berpikir kritis siswa dalam penyajian materi pembeljaran matematika relasi dan fungsi dalam desain pembelajaran the power of two dengan menggunakan observasi, tes lisan dan tes tulis.

\section{HASIL PENELITIAN DAN PEMBAHASAN}

Berdasarkan permasalahan pertama tentang rendahnya minat belajar matematika siswa kelas VIII SMP Negeri 1 Sakra Barat, yang berdasarkan hasil angket minat siswa terhadap pembelajaran Matematika yang dilakukan pada tanggal 14 Juli 2018, dan dilanjutkan dengan tindakan pemberian angket respon siswa terhadap komponen kegiatan pembelajaran matematika pada tanggal 14 Agustus 2018, dengan tujuan mengetahui akar permasalahan.

Menurut hasil analisa angket respon siswa terhadap komponen kegiatan pembelajaran matematika, pada 4 aspek penilaian yakni tingkat perhatian, relevansi, confidance, dan kepuasan, juga rendah dengan kategori rata-rata masing-masing aspek sangat kurang. Mengacu pada hasil inilah peneliti menyimpulkan bahwa akar permasalahan dari rendahnya minat belajar matematika siswa kelas VIII SMP Negeri 1 Sakra Barat adalah kurangnya sikap berpikir kritis.

Berdasarkan hasil tindakan penelitian terhadap permasalahan yang dihadapi siswa melalui penerapan model pembelajaran the power of two, diperoleh data baik secara data kualitatif dan kuantitatif dari kegiatan pertama dan kedua mengalami peningkatan. Secara kualitatif perkembangan sikap, dan penerimaan siswa terhadap penerapan model the power of two dikatakan bisa menumbuhkan sikap berpikir kritis siswa. Hal ini di buktikan dengan peningkatan suasana pembelajaran pada siklus II dimana siswa dengan semangat melaksanakan tahapan pembelajaran the power of two. 


\section{KESIMPULAN}

Model pembelajaran the power of two belum dapat meningkatkan kemampuan berpikir kritis siswa kelas VIII SMP negeri 1 Sakra Barat semester ganjil Tahun pelajaran 2018/2019, karena hasil evaluasi pengetahuan siswa hanya mencapai angka rata-rata 73,67 sedangkan asumsi umum sebuah penelitian dikatakan berhasil jika didapatkan angka $=>75$. Tapi peningkatan pada komponen penilaian yang mendukung sikap kritis siswa dalam proses pembelajaran pada setiap siklus tindakan dapat dijadikan acuan tentang keabsahan teori the power of two untuk menunjang suasana pembelajaran yang terpusat pada siswa.

\section{DAFTAR PUSTAKA}

Charisma Dita Ayuningtyas, Ngurah Ayu N.M., Affandi Faisal.K.2013. Pengaruh Model Pembelajaran Aktif Dengan Metode The Power Of Two Dan Make A Match Terhadap Hasil Belajar Siswa Kelas X SMA Negeri 1 Sale. Lontar Physics Forum

Hassoubah, 2004, Kemampuan berpikir Kritis dan Kreatif, Rosda Karya bandung;

Hisyam, Zaini. 2002. Strategi Pembelajaran Aktif di PT Yogyakarta: CTDS.

Istarani. 2012. 58 Model Pembelajaran Inovatif. Medan : Media Persada

Moleong,2002, Metodologi Penelitian, Rosda Karya Bandung;

Mulyasa, 2009, Kurikulum Yang Disederhanakan Pengembangan Standar Kompetensi dan Kompetensi Dasa, (Bandung: PT: Remaja Rosdakarya)

Ngalim Purwanto, 2009, Prinsip-prinsip dan Teknik Evaluasi Pengajaran, Bandung: PT Remaja Rosdakarya;

Rahman Asy'ari, dkk, 2017, Buku Guru Matematika Kelas VIII, SMP/MTs, Kementerian Pendidikan dan Kebudyaan RI

Sri Wardani, 2010, Implikasi Karakteristik Matematika dalam pencapaian Tujuan Mata pelajaran Matematika di SMP/MTs, Departemen Pendidkan Nasional, Ditjen P4TK Jakarta.

Suharsimi, 2008, Penelitian Tindakan Kelas, Bumi Aksara Jakarta:

Unila.ac.id.2012, Pendekatan Kualitatif dalam penelitian, http://blog.unila.ac.id/ diakses 25 Agustus 2018.

Wina Hariyasti. 2014.Strayegy The power Of Two, http://winasinaga.blogspot.com akses 24 Juli 2018 